\title{
Flipped Higher Education Classroom: An Application in Environmental Education Course in Primary Education
}

\author{
Özkan Yılmaz \\ ${ }^{1}$ Faculty of Education, Erzincan University, Erzincan, Turkey \\ Correspondence: Özkan Y1lmaz, Faculty of Education, Erzincan University, Erzincan, 24100, Turkey. E-mail: \\ ozkanyilmaz@erzincan.edu.tr
}

Received: June 30, 2017

Accepted: July 11, 2017

Online Published: August 6, 2017

doi:10.5539/hes.v7n3p93

URL: http://doi.org/10.5539/hes.v7n3p93

\begin{abstract}
Usage of technology in educational settings is becoming a standard for 21 st century's learners. Flipped classroom presents an entirely new learning environment based on technology for students, thus requiring different research for establishing effective learning and teaching.

This paper aimed to explore usability of flipped classroom in higher education from the perspective of students' experience. The study participants are undergraduate students who are enrolled department of primary education in faculty of education. In study used a mixed-method to answer research questions. Students were post tested on usage of flipped classroom model in the frame of instructional materials attitude. And, focus group interview used to get students' perceptions. One of the more significant findings to emerge from this study is that students' attitude toward the flipped classroom were positive. The second major finding was that flipped classroom model is effective on: (1) Instruction and learning environment, (2) Individual changes.
\end{abstract}

Keywords: flipped classroom, higher education, learning environment, students' perception

\section{Introduction}

Using technology in educational settings is becoming a standard for 21 st century's learners. The Internet changed the instruction and learning model. Learner can use internet for learning activity any time and teacher also use it for distance instruction. Today, numbers of learner are taking distance and blended courses from educational institutions (Gemin, Pape, Vashaw, \& Watson, 2015; Staker, 2011). In order to effectively use the technology, we need to develop new instructional strategies, methods and techniques that are learner-centered (Gillani, 2003). This article aimed to explore usability of flipped classroom in higher education from the perspective of students' experience.

This study is aimed to reveal;

How are the attitudes of preservice class teachers about flipped classroom model?

According to student perspectives, how the flipped classroom has its effects on learning and teaching environment?

\subsection{Background of Study}

In twenty-first century, there is a trend toward usage of digital resources and communication tools in education (Kong, 2015). These tools provide teachers to help students exemplify and understand concepts easily through animations or various computer models, and it gives chance teachers and students to make contact with peers and experts anywhere on the world (Zucker, 2008). It is one of the important goal in higher education in the 21 st century to reform teacher education programs through the establishing the active learning environments that support students learning (Keengwe, Onchwari, \& Onchwari, 2009). At that point, it is important to designing learning environment through to students need.

\subsection{The Starting Point of Flipped Classroom}

In 21st century, the idea of flipped classrooms is enables students to access resources without any a specific place in limited time. In the early of 1990s, Gall, Gall, Jacobsen, and Bullock (1990) designed special instruction content for physics courses. Students' activities in classroom settings were asking questions, laboratory, and sections. In the context of education software were clicking words, symbols, interactive simulation, interactive 
problems. The idea was that provide students to choose content their individual needs. In 2007, two science teachers asked that question "What if we prerecorded all of our lectures, students viewed the video as 'homework', and then we used the entire class period to help students with the concepts they don't understand?" (Eldredge, 1990). They used "flipped classroom" concept for that model. Aims of these studies were how was provide a personalized education for each student.

\subsection{Theoretical Foundations of the Flipped Classroom}

The theoretical foundation of flipped classroom is that students receive a personalized education tailored to their individual needs (Akey, 2006; Eldredge, 1990). The teacher who has a hundred students in a course doesn't have a chance to establish a personalized education in the traditional educational setting. The weakness of the traditional approach is that all students have different knowledge in a specific topic, and not all of them come to class prepared to learn (Eldredge, 1990).

Brame (2013) identified four key elements of the flipped classroom based on students' developing and understanding of factual knowledge in the context of a conceptual framework:

- Provide an opportunity for students to gain first exposure prior to class.

- Provide an incentive for students to prepare for class.

- Provide a mechanism to assess student understanding.

- Provide in-class activities that focus on higher level cognitive activities.

In addition and more specifically, flipped learning is a flexible learning environment. FLN (2014) was defined the four pillars of F-L-I-P. The first pillar is flexible environment: it allows creating flexible spaces in which students choose when-where they want to learn. The second pillar is learning culture: students are actively involved in knowledge construction based on a learner-centered approach. Pillar three is intentional content: educators determine what they need to teach and what kind of materials student should use for maximizing classroom time in order to active learning strategy. The final pillar is professional educator: instructor must actively scaffold learning with continuously observe students and give feedback, and assessing their work to support self-directed learning.

\subsection{The Flipped Classroom in Practice}

The flipped classroom has no specific model (Srivastava, 2014). Also, researcher called this educational setting such as; "flipped classroom strategy" (Kong, 2015), "flipped classroom learning model" (Akın, 2016), "instructional model" (McLean, Attardi, Faden, \& Goldszmidt, 2016; Wang, X., Wang, J. P., Wen, Wang, J., \& Tao, 2016). Flipped classroom is an active, learner-centered teaching model which is designed to improve students' performance (Aşıksoy \& Özdaml1, 2016; Srivastava, 2014).

In the traditional model, students need to do their homework at home. Some of homework problems cause confused student in class. The teacher needs to do warm-up activity and solve those problems before the present new content (Eldredge, 1990). In the flipped model, learning tasks typically do as homework. Teachers use class time to make meaningful contact with students guiding, feedback, and helping for their individual needs (Kong, 2015). If students need to ask questions about the content, teacher usually answers these questions during the first few minutes of class (Eldredge, 1990). But, it doesn't take time as much as traditional model. Eldredge (1990) illustrated class time in traditional versus flipped classrooms (See Table 1).

Table 1. Comparison of traditional classroom versus flipped classroom

\begin{tabular}{llll}
\hline Traditional Classroom & \multicolumn{2}{l}{ Flipped Classroom } \\
\hline Activity & Time & Activity & Time \\
Warm-up activity & $5 \mathrm{~min}$. & Warm-up activity & 5 min. \\
Go over previous night's homework & $20 \mathrm{~min}$. & Q\&A time on video & $10 \mathrm{~min}$. \\
Lecture new content & $30-45 \mathrm{~min}$. & Guided and independent practice and/or lab activity & 75 min. \\
Guided and independent practice and/or lab activity & $20-35 \mathrm{~min}$. & & \\
\hline
\end{tabular}


Warming-up activities are a necessity for all instructional environments in schools, and need guidance by instructor. Those activities need to preparations for learning in classroom. In traditional classroom, teacher use much more time after the warming-up activities. Students have questions about the previous night's homework. The teacher should answer those questions before the start new content of lecture. On the other side, there is no homework in flipped classroom. So, teacher use much more time for guiding the students' learning practice in class or lab activity.

\section{Method}

This study used a mixed-method to answer research questions. Students were post tested on usage of flipped classroom model in the frame of instructional materials attitude. And, focus group interview used to get students' perceptions.

\subsection{Variables}

In quantitative dimension, used "flipped classroom model" was an independent variable, and students' attitudes toward flipped classroom model was dependent variable. In qualitative dimension, users' perceptions were used to evaluate effect size of "flipped classroom model" in learner view. Operational definitions of all variables are listed below.

\subsection{The Flipped Classroom Model}

The flipped classroom model is functionally defined as an instructional model in which students receive conceptual knowledge through online videos, animations, hypertext, and various document on the internet environment before class. In-class, students ask to teacher and answer questions about the subject and engage in active learning activities where they practice what they learned from the digital document they read and viewed. After all learning activities, the whole class discussion and evaluation do with teacher guidance.

\subsection{Attitude}

The dependent variable is students' attitude toward the flipped classroom model in instruction and learning environment. Students' attitude was measured with the modified Instructional Material Motivation Survey (IMMS). The IMMS was developed to measure learners' motivation toward instructional materials (Keller, 1993).

\subsection{Users' Perception}

The users' perception is students' views based on their experiences from flipped classroom model in Environmental Education class.

\subsection{Participants}

Participants for this study were 31 (25 men and 6 women) undergraduate students in the Department of Primary Education program, Faculty of Education. Participants included all students enrolled in Environmental Education during the fall terms of 2015. The average ages of participants were 19.

\subsection{Measure}

Students' attitude, toward the flipped classroom model, was measured by Instructional Material Motivation Survey (IMMS). This survey origin is in the ARCS motivational design model (Keller, 2010). It is based on human motivation literature, and it can be used to measure attitude toward a treatment $(\mathrm{Oh}, 2006)$. Originally, the survey was contained of 36 items gathered under four sub-factors. These are attention, relevance, confidence, and satisfaction. The adaptation of instructional materials motivation survey to Turkish was made by Kutu and Sozbilir (2011). The Turkish version of survey was constructed from 24 items gathered two sub-factors. First factor was called Attention-Relevance, reliability coefficient (cronbach alpha, $\alpha$ ) calculated as 0.79 , and second factor was called Confidence-Satisfaction, reliability coefficient (cronbach alpha, $\alpha$ ) calculated as 0.69 . For the whole survey reliability coefficient $(\alpha)$ was calculated as 0.83 .

Data from IMMS was analyzed two sub-factors (Attention-Relevance and Confidence-Satisfaction). The format of IMMS was a typical five-level Likert item (strongly disagree (1), low-level agree (2), mid-level agree (3), high-level agree (4), strongly agree (5)). To evaluate means gathered from data, ranges accepted as 1.00-1.80 "strongly low-level", 1.81-2.60 "low-level", 2.61-3.40 "mid-level", 3.41-4.20 "high-level", 4.21-5.00 "strongly high-level".

The survey was applied at the end of term via electronic form. The reliability coefficient $(\alpha)$ calculated as 0.84 . For sub-factors reliability coefficient $(\alpha)$ calculated as 0.73 (Attention-Relevance), 0.72 (ConfidenceSatisfaction). Descriptive analyzing method was used to explore data. 
Students' perception, toward the flipped classroom model, was measured by researcher-administered survey. The survey was included 9 open-ended questions to gather perception. The analyzing was made by NVivo Pc software.

NVivo support the analyst in making use of multiple strategies such as reading, reflecting, coding, annotating, memoing, visualizing... etc. Each of these strategies is integrated in a process of learning from the data (Bazeley, 2007). Node was used to indicate connection in a branching network to explore dimensions of students' perceptions. First step, free nodes were used to store all coding, presumed no relationships or connection. Second step, special parent nodes were used from free nodes to branching structures of user perception. The last step, nodes were collected special themes and presented via figure.

\subsection{Procedures}

The procedures of the present study were carried out at the Faculty of Education, during the first term of the 2015/2016 academic year within the "Environmental Education" course. After implementing the flipped classroom, IMMS test was administered to all participants, and focus group interview was used to get students' views. As for using the flipped classroom, it lasted for 10 weeks, and 50+50 minutes in each of week.

\subsection{Planning for the Flipped Classroom}

In order to prepare the web based content, course objectives were identified, learning outcomes for each lecture were determined, and content coverage was defined. Various video prepared for every lecture. Also, some of lecture was included reading text activity. All the knowledge or skill points in each lecture were included in different videos (possible to web viewing and download). Each video lasted 2-20 minutes. The researcher utilized video and reading text resources from many websites such as YouTube and eba (https://www.eba.gov.tr).

Flipped classroom platform is established according to the need of learning characteristics and learning outcomes for each lecture. Learning Management System (LMS) was used to arrange all content in web platform. This provided students a quick and easy access to all the materials of the course from anywhere of outside of school.

The Moodle (Modular Object-Oriented Dynamic Learning Environment) platform an Open Source Learning Management System (OSLMS) was used in this study. On the Moodle, all course content was separated as a 10 -week learning event. Each of weeks was included specific reading text activity or video, or both of them. Students used their user and password to enter Moodle.

Because all students were not accustomed to the flipped classroom experience, during a class orientation session, the researcher introduced the notion of the flipped classroom model, explained the basic ideas of model, and demonstrated how to operate online via Moodle. The researcher showed structure and function of the Moodle. Also, researcher explained requirements for online activity, the explanation of some examples, and answered to students' questions.

\subsection{Implementation of the Flipped Classroom}

This phase consisted of three parts: outside the classroom, during the classroom, and end of course according to the adopted definition of the flipped classroom model used in instruction of Environmental Education.

\subsubsection{Outside the Classroom}

Main components of this preparation was watching videos and reading in order to obtain the basic knowledge before lecture. They had the opportunity to watch each video and read all text on webpages. Also, all content could be downloadable for studying without internet connection in anytime. Students routinely did these activities outside the classroom, every week.

\subsubsection{During the Classroom}

A variety of learning activity designed to engage the students more deeply in the process of learning and to enhance their learning opportunities in the classroom. First, the teacher began class time by asking questions to assess students' understanding of the basic concepts presented in the assigned videos and reading text. So that students motivated to subject. Second, teacher gave expert group a short time (10-15min.) to present information about content of subject. Students were divided into ten groups. Then all students seated their own working group to make learning activity. Students created, collaborated, and put into practice what they learned from the lectures they viewed outside class and presented information by expert group inside class. Students had opportunity to watch videos, read text, and surfing internet to reach knowledge in the classroom. Various learning activity were used (e.g., concept mapping, creating drama activity, whole-class discussion, mind 
mapping, flowcharting, concept cartoon, puzzles). During the class activity, teacher gave feedback to students, summarized key concepts, and evaluated of related learning activity. The Figure 1 below shows the examples from student works and photos in-class activity.

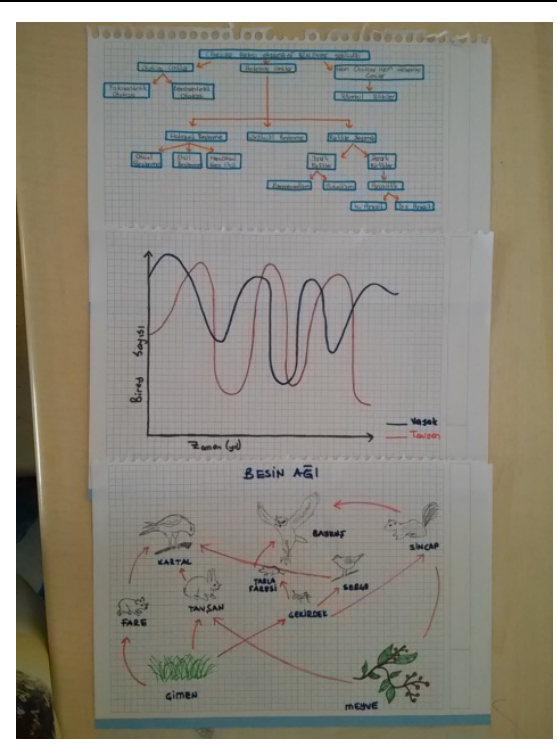

Concept map, Graphic, flowcharting

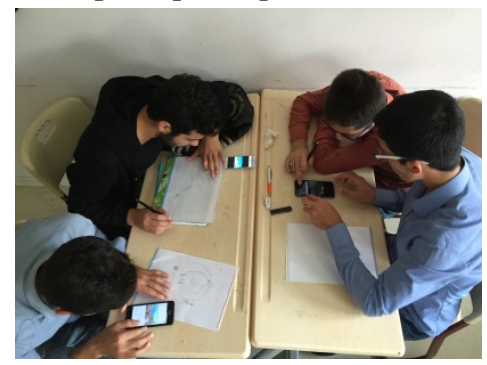

Students workgroup

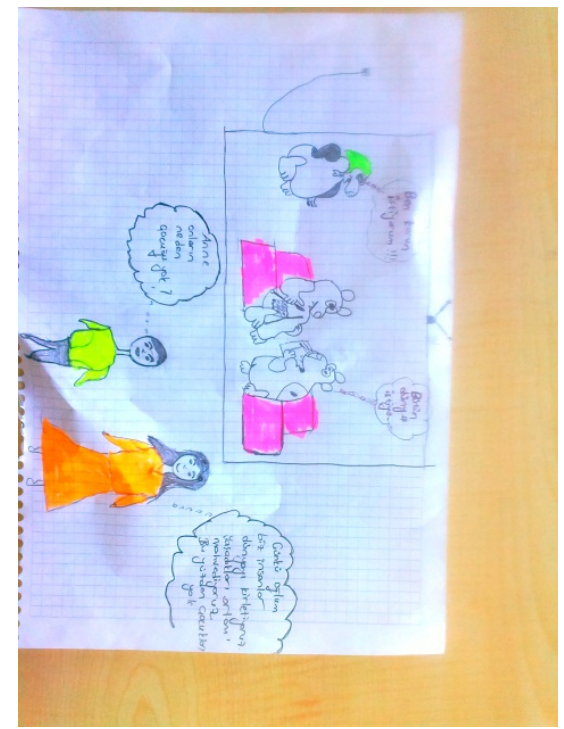

Concept cartoon

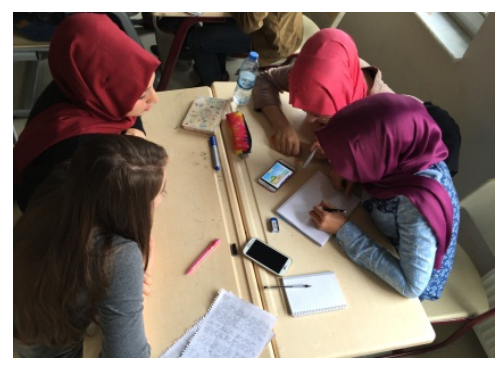

Students workgroup

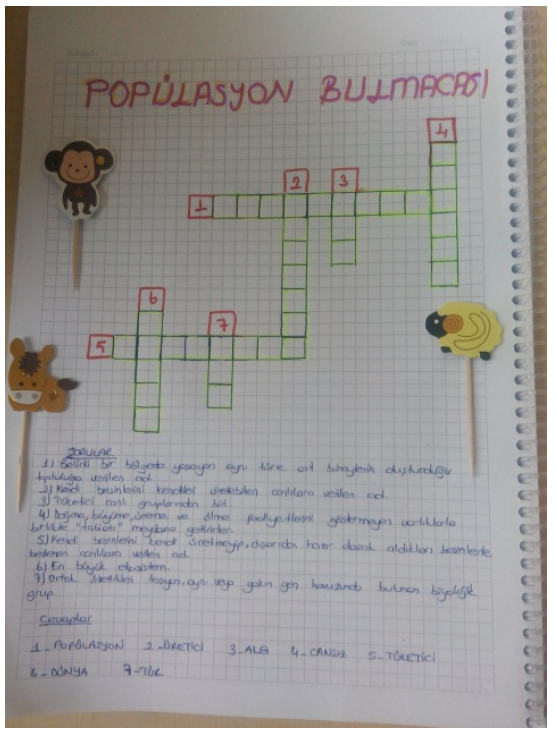

Crossword puzzle

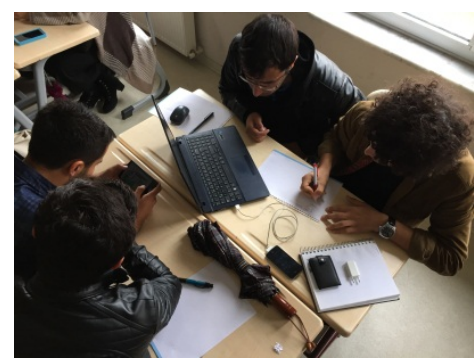

Students workgroup

Figure 1. Students workgorup and samples of in-class studies

\subsubsection{End of the Course}

End of course, teacher summarized all new concepts based on leading outcomes in the course and gave information about next week learning activity. Also, teacher answered students' questions about subject or next week activity. After the class, students uploaded their group work (as seen on Figure 1) to the Moodle. Teacher grade uploaded work in the same day at evening. So that, students had opportunity to saw how was their performance in the class.

\section{Results and Discussion}

In order to assess students' attitudes toward flipped classroom model, posttest was used. It can be seen from the data in the histogram in Figure 2 indicates that students' attitude is very few difference (around 2-4) in term of items score. There are some differences between sub-factors (attention-relevance and confidence-satisfaction) score. 


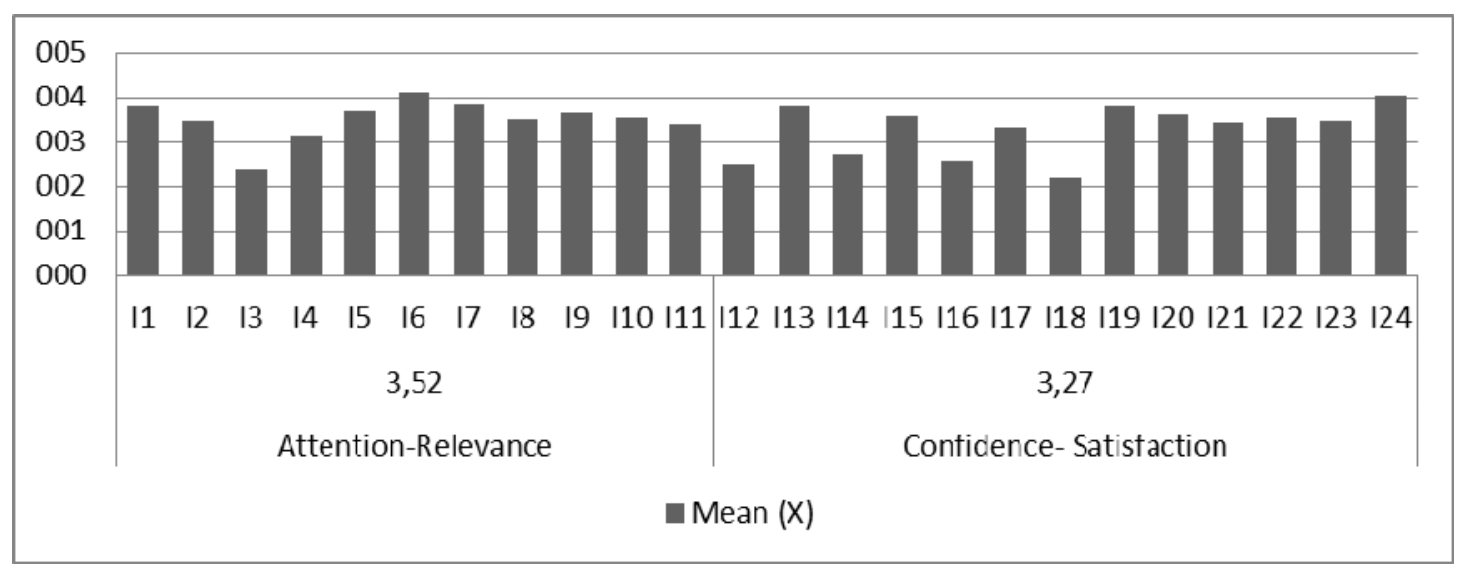

Figure 2. Students' attitude

From the graph above we can see that the mean score for attention-relevance $(x=3.52$, high-level $)$ higher than the mean score for confidence-satisfaction ( $\mathrm{x}=3.27$, mid-level). And, mean score for IMMS is mid-level $(\mathrm{x}=3.38)$. These results show that flipped classroom have positive effect on students' attitude.

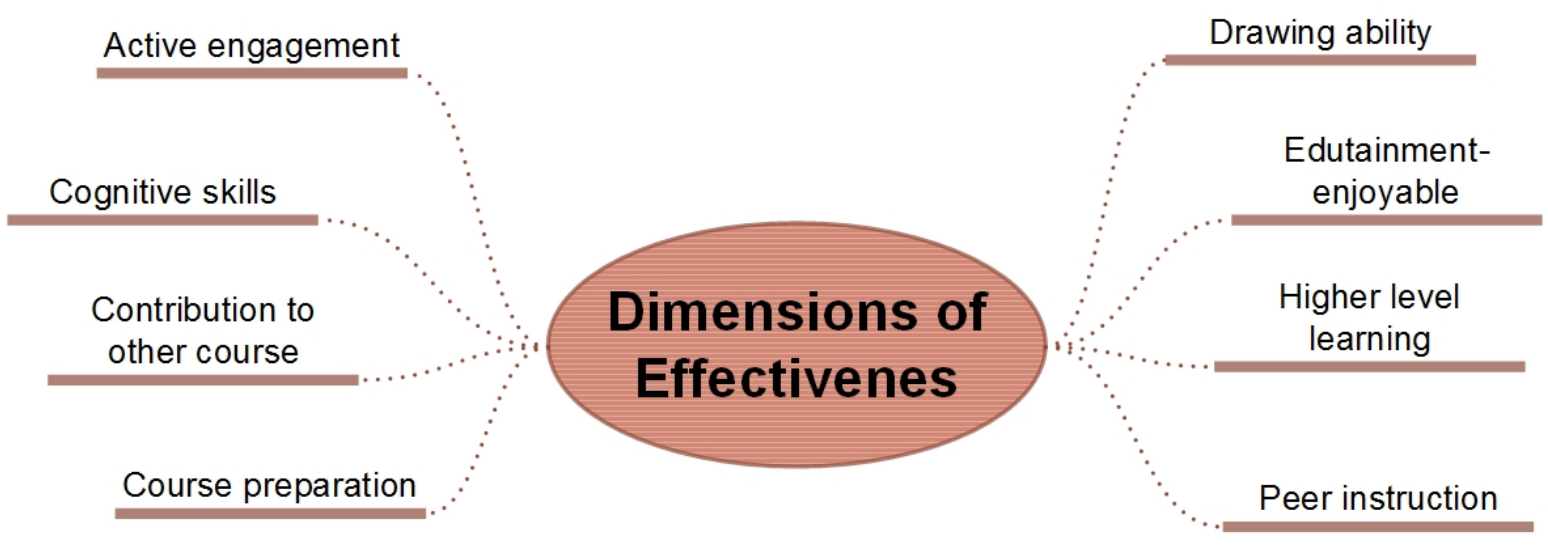

Figure 3. Dimension of effectiveness

Students' perception, toward the flipped classroom model, was measured by researcher-administered survey. The overall response to this survey was collected two themes. These are (1) dimensions of effectiveness, (2) problems. It can be seen from the Figure 3 that the dimensions of effectiveness theme have eight branches.

Active engagement: This node was referenced three times. A student expressed that "... In this model, student is much more active and interest in learning in classroom. And, it cause effective knowledge sharing in class..." Student engagement involves both behaviors (attention, effort, etc.) and emotions (interest, enthusiasm, etc.) (Council, 2003). Behavioral engagement includes students' attendance and active participation in class activities (Harris, 2011). Also, engagement can be regarded as the driving force of learning and relates to students' personal investment that is affect students' quality of life (Harris, 2011; OECD, 2004).

In flipped classroom, students did various activities by themselves or with group friends. All activities were done by teacher guidance. Student's statement shows that engagement was supported dimensions of behaviors and emotions, with flipped classroom model.

Cognitive skills: This node was referenced two times. A student stated that “... everyone think and an idea pop into someone's head. But it's hard to organize and write to a paper. We did some writing activity in class. Now we can write our idea thought directly. It's a plus for us...". Writing is related to cognitive skills (Freedman, Pringle, \& Yalden, 2014). With writing activities, person is refining and consolidating new ideas with prior knowledge. Also, writing appears to enhance the retention of co-constructed knowledge (Rivard \& Straw, 2000). 
Writing skills require systematic training (Kellogg, 2008). In schools, unfortunately a large percentage of students never gain this area. Because they don't write very much or very often (Herr, 2008). In flipped class, students had writing and presenting opportunities via various in-class activities. The statement above shows that learner's cognitive skills were positive affected by designed learning environment (flipped class).

Contribution to other courses: This node was referenced one time. The student expressed that “... If we think a short time, we have drama course in next year. We can think... as a rehearsal for it". Curriculum is an important factor for education. In instruction, teacher use specific curriculums for every course. But, a course cannot be considered independent of the other one. In literature, it's called interdisciplinary (Schwarzer \& Grinberg, 2017). In education, interdisciplinary is the act of making a connection between disciplines through instruction (Schwarzer \& Grinberg, 2017). Curriculum, based on interdisciplinary, supports a more relevant, less fragmented, and stimulating experience for student (Jacobs, 1989). The student's statement above shows that some activities which were done in environmental education course supports to different courses. The flipped classroom model seems to effective on contribution to other course.

Course preparation: This node was referenced three times. A student stated that "How can I say, for instance, we are studying before class, maybe not all of friends study well, all of us read at least one time before starting a new subject and then doing in-class activities are well for us...". Students' prior knowledge has important implications for learning and minimizes the potential confusion among similar type of information. Also, it plays a serious role in perception (Gredler, 2009). In flipped classroom model, students obtained the basic knowledge before lecture. The student statements above show that pre-studies positive effective on course preparation. And, it has potential to help minimize confusing information which is related to subject.

Drawing ability: This node was referenced one time. The student expressed that "I improved my drawing ability". Drawing can be seen as a way of expressing the students' own thoughts or ideas just like speaking or writing. At that point, practice is the key role of advancing of any abilities. As can be seen from the students' statement, the student made much more practice on drawing activities. And, it had positive affect on drawing ability.

Edutainment-enjoyable: This node was referenced four times and also the most referenced from all nodes. A student stated that "... I agree. There were new fun activities in every week. It was not boring, also much more enjoyable. We learnt enjoyable as the kids...". Bisson and Luckner (1996) stated that fun have four characteristics inherent. These are "relative", "situational", "voluntary experience" and the last one "inherent to our nature". To provide a useful experience in learning environment, fun in education need to linked to the subject (Baid \& Lambert, 2010). Fun and experiencing enjoyment are seeming as a motivator to attend class (Lucardie, 2014). As can be seen on literature, fun is an important factor for class. In flipped classroom, students have opportunity to make different activities. These activities support to fun and enjoyable learning environment. The most striking result to emerge from the data is that this node is the most referenced from all nodes.

Higher level learning: This node was referenced one time. The student stated that "We are studying in a group. Every person talking about owns idea and then we discussing. The discussing helps us to find what is the best..., in other words we are reaching the last point of success... We are reaching the highest level of comprehension... learning level". In education, Bloom's categories use to write learning objectives. Bloom, Englehart, Furst, Hill, and Krathwohl (1956) are classified form of learning into three categories: cognitive, affective and psychomotor domains. They identified six levels of learning which represented increasing levels of cognitive complexity, from the lowest level of knowledge, to more advanced levels of analysis, synthesis, and evaluation. The higher level of cognitive skills causes deeper learning and transfer (Adams, 2015). In flipped classroom model, students did communication with group friends, whole class and also the teacher. They were active almost all the class time. As student statement shows, talking about ideas and discussing in the classroom are positive effect on students' higher level learning.

Peer instruction: This node was referenced two times. A student stated that “ $\ldots$ because, all we are doing group activity. All activities based on collaborative education model that's mean if your friends don't want to do some activities, you should warn to them and persist for attending to activities... you should engage your friends to active participation. (Other student added)... I did not have enough information about my friends' knowledge about a subject. Also, they did not know about my knowledge. We share knowledge all together". Winston and Zimmerman (2003), defined peer effects “exist when a person's behavior is affected by his or her interaction with one or more other people". From the expression of the student, it is apparent that students have an impact on each other's behavior. In learning activity, they force group friends to do in-class activities. Also, they are sharing own information in the direction of their goals with peers. 
With peer instruction, students find the chance to interact with friends during the lectures and attention on concepts (Mazur, 1997). Flipped classroom model together with the in-class activities seems effective in enhancing student learning under peer instruction.

It can be seen from the Figure 2 that the dimensions of effectiveness theme have nine branches. Additionally, students expressed their problems for using of flipped classroom model in Figure 4. As can be seen on Figure 4 there are two nodes about problems.

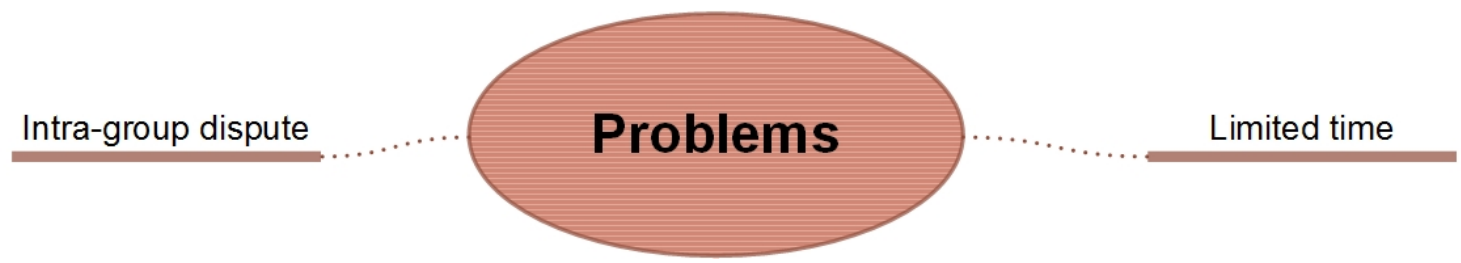

Figure 4. Problems in flipped classroom model

Intra-group dispute: This node was referenced one time. The student stated that “ $\ldots$ for instance, we are three friends in a group. Suppose that a friend did not come to class, for 2-3 weeks, we are doing all activity instead of $\mathrm{him} /$ her. And, for example we have a drawing work in-class activity. A member of group did not participating in-class activity. Also, he/she did not offer any idea. Teacher doesn't know that problem because it is a group task".

In flipped classroom, students did collaborative learning tasks. It needed to make cooperation with other friends. Collaboration, group work and cooperative learning often use in education. But without careful planning and monitoring by the teacher, learning can be negatively affected (Woolfolk, Hughes, \& Walkup, 2008). From the student expression above we can see that intra-group dispute is a problem in class.

Limited time: This node was referenced three times. A student stated that "Sometimes, we have a problem with the time [in-class activity]. Because, finding an idea and write papers are taking a time. We need an extra time for finding an idea and make practice. So, it will be much more useful". In a lesson, there are different sessions such as initiation, teacher activities, student activities, assessment, and closure (Larson \& Keiper, 2007). Time is an important factor for the lesson. All these sessions are done with in the lesson plan. As shown in student expression, student doesn't use time effectively in-class activities. They were complained about limited time.

In summary, students' attitudes toward flipped classroom were positive. Specially, attention-relevance dimension of attitude was higher-level (see Figure 2). Further analysis based on students' expressions showed that flipped classroom effective on encouraging active engagement (see Figure 3). A comparison of the two results (quantitative and qualitative) showed that flipped classroom model effective on higher education context. Student-to-student interactions in the classroom are significantly and positively related to engagement (Akey, 2006). As seen in Figure 3, flipped class is also effective on peer instruction. With flipped class, students have had much more opportunity to interact with friends in class activities. Flipped class was not only the positive effect on two elements. It also was positive effect on students' cognitive skills, course preparation, drawing ability, and higher level learning. Students have liked new learning environment (described as edutainment-enjoyable) and the flipped classroom model has been effective on contribution to another course. Besides positive effects of flipped class, there are two important problems (intra-group dispute and limited time) need to solve for getting an efficient effect with flipped classroom model.

\section{Conclusion}

The present study was designed to explore usability of flipped classroom in higher education from the perspective of students' experience. One of the more significant findings to emerge from this study is that students' attitude toward the flipped classroom were positive.

The second major finding was that flipped classroom model is effective on: (1) Instruction and learning environment: active engagement, contribution to courses, edutainment-enjoyable classroom environment, peer instruction, (2) Individual changes: cognitive skills, course preparation, drawing ability, higher level learning.

It was also shown that there are two problems for using of flipped classroom model: (1) Intra-group dispute, (2) Limited time. 
The evidence from this study suggests that flipped classroom can be used in higher education. It is contribute to learning and instruction. With it, two important factors should be considered when it used. If group study based on co-operation is to be carried out, attention should be paid to the formation of groups. Also, in-class activities should be designed with proper timing and planning. It is suggested that the association of these factors is investigated in future studies.

\section{References}

Adams, N. E. (2015). Bloom's taxonomy of cognitive learning objectives. Journal of the Medical Library Association: JMLA, 103(3), 152-153. https://doi.org/10.3163/1536-5050.103.3.010

Akey, T. M. (2006). School context, student attitudes and behavior, and academic achievement: An exploratory analysis. Retrived from https://eric.ed.gov/?id=ED489760

Akın, E. (2016). Flipped classroom learning model and its availability in Turkish Education. Journal of Education and Training Studies, 4(11), 100-108. https://doi.org/10.11114/jets.v4i11.1825

Aşıksoy, G. L. M., \& Özdamlı, F. (2016). Flipped classroom adapted to the ARCS model of motivation and applied to a physics course. Eurasia Journal of Mathematics, Science \& Technology Education, 12(6), $1589-1603$.

Baid, H., \& Lambert, N. (2010). Enjoyable learning: The role of humour, games, and fun activities in nursing and midwifery education. Nurse Education Today, 30(6), 548-552. https://doi.org/10.1016/j.nedt.2009.11.007

Bazeley, P. (2007). Qualitative Data Analysis with NVivo. 1 Oliver's Yard 55 City Road London EC1Y 1SP: SAGE Publications Ltd.

Bisson, C., \& Luckner, J. (1996). Fun in Learning: The pedagogical role of fun in adventure education. Journal of Experiential Education, 19(2), 108-112. https://doi.org/10.1177/105382599601900208

Bloom, B. S., Englehart, M. D., Furst, E. J., Hill, W. H., \& Krathwohl, D. R. (1956). Taxonomy of educational objectives. In The classification of educational goals, Handbook 1: Cognitive Domain. New York: Longmans, Green, Co.

Brame, C. J. (2013). Flipping the classroom. Retrieved December 24, 2016, from http://cft.vanderbilt.edu/guides-sub-pages/flipping-the-classroom/

Council, N. R. (2003). Engaging Schools: Fostering High School Students' Motivation to Learn. Washington, DC: The National Academies Press.

Eldredge, J. L. (1990). Learning and Study Strategies Inventory-High School Version (LASSI-HS). Journal of Reading, 34(2), 146-149.

FLN. (2014). Definition of flipped learning. Retrieved December 29, 2016, from http://flippedlearning.org/definition-of-flipped-learning/

Freedman, A., Pringle, I., \& Yalden, J. (2014). Learning to Write: First Language/Second Language. Taylor \& Francis.

Gall, M. D., Gall, J. P., Jacobsen, D. R., \& Bullock, T. L. (1990). Tools for Learning: A guide to teaching study skills. United States of America: Association for Supervision and Curriculum Development.

Gemin, B., Pape, L., Vashaw, L., \& Watson, J. (2015). Keeping pace with K-12 digital learning. Retrieved October 25, 2016, from http://www.kpk12.com/reports/

Gillani, B. B. (2003). Learning Theories And The Desing Of E-Learning Environments. Lanham: University Press of America.

Gredler, M. E. (2009). Learning and instruction: Theory into practice (6th ed.). Upper Saddle River, N.J.: Merrill Pearson.

Harris, L. (2011). Secondary teachers' conceptions of student engagement: Engagement in learning or in schooling. Teaching and Teacher Education, 27, 376-386. https://doi.org/10.1016/j.tate.2010.09.006

Herr, N. (2008). The sourcebook for teaching science, grades 6-12: Strategies, activities, and instructional resources (1st ed.). San Francisco, CA: Jossey-Bass.

Jacobs, H. H. (Ed.). (1989). Interdisciplinary curriculum: Design and implementation (p. 99). Association for Supervision and Curriculum Development, Alexandria, Va. 
Keengwe, J., Onchwari, G., \& Onchwari, J. (2009). Technology and student learning: Toward a learner-centered teaching model. Association for the Advancement of Computing in Education Journal, 17(1), 11-22.

Keller, J. M. (1993). Instructional Material Motivation Survey. The Florida State University.

Keller, J. M. (2010). Motivational design for learning and performance. USA: Springer Science Business Media. https://doi.org/10.1007/978-1-4419-1250-3

Kellogg, R. T. (2008). Training writing skills: A cognitive developmental perspective. Journal of Writing Research, 1(1), 1-26. https://doi.org/10.17239/jowr-2008.01.01.1

Kong, S. C. (2015). An experience of a three-year study on the development of critical thinking skills in flipped secondary classrooms with pedagogical and technological support. Computers \& Education, 89, 16-31. https://doi.org/10.1016/j.compedu.2015.08.017

Kutu, H. 1., \& Sozbilir, M. (2011). Adaptation of instructional materials motivation survey to turkish: A validity and reliability study. Necatibey Faculty of Education Electronic Journal of Science and Mathematics Education, 5(1), 292-312.

Larson, B. E., \& Keiper, T. A. (2007). Instructional Strategies For Middle And High School. 270 Madison Avenue New York, NY 10016: Routledge Taylor \& Francis Group.

Lucardie, D. (2014). The Impact of Fun and Enjoyment on Adult's Learning. Procedia-Social and Behavioral Sciences, 142, 439-446. https://doi.org/10.1016/j.sbspro.2014.07.696

Mazur, E. (1997). Peer instruction: A user's manual. Upper Saddle River, N.J.: Prentice Hall.

McLean, S., Attardi, S. M., Faden, L., \& Goldszmidt, M. (2016). Flipped classrooms and student learning: Not just surface gains. Adv Physiol Educ, 40, 47-55. https://doi.org/10.1152/advan.00098.2015

OECD. (2004). Student Learning: Attitudes, engagement and strategies. Learning for Tomorrow's World-First Results from PISA 2003. https://doi.org/10.1787/9789264006416-4-en

Oh, S. Y. (2006). The effects of reusable motivational objects in designing reusable learning object-based instruction (Doctor). Florida State University, Florida State University Libraries.

Rivard, L. P., \& Straw, S. B. (2000). The effect of talk and writing on learning science: An exploratory study. Science Education, 84(5), 566-593. https://doi.org/10.1002/1098-237X(200009)84:5<566::AID-SCE2>3.0.CO;2-U

Schwarzer, D., \& Grinberg, J. (2017). Successful Teaching: What Every Novice Teacher Needs to Know. Rowman \& Littlefield Publishers.

Srivastava, K. (2014). Role of flipped classroom in education. Paripex Indian Journal of Research, 3(4), 81-83. https://doi.org/10.15373/22501991/APR2014/27

Staker, H. (2011). The rise of K-12 blended learning: Profiles of emerging models. Retrieved October 25, 2016, from http://www.innosightinstitute.org/innosight/wp-content/uploads/2011/05/The-Rise-of-K-12-Blended-Learni ng.pdf

Wang, X. H., Wang, J. P., Wen, F. J., Wang, J., \& Tao, J. Q. (2016). Exploration and practice of blended teaching model based flipped classroom and SPOC in higher university. Journal of Education and Practice, 7(10), 99-104.

Winston, G. C., \& Zimmerman, D. J. (2003). Peer Effects in Higher Education. National Bureau of Economic Research. https://doi.org/10.3386/w9501

Woolfolk, A., Hughes, M., \& Walkup, V. (2008). Psychology in Education. Madrid: Pearson Education Limited.

Zucker, A. A. (2008). Transforming schools with technology: How smart use of digital tools helps achieve six key education goals. Cambridge, MA: Harvard Education Press.

\section{Copyrights}

Copyright for this article is retained by the author(s), with first publication rights granted to the journal.

This is an open-access article distributed under the terms and conditions of the Creative Commons Attribution license (http://creativecommons.org/licenses/by/4.0/). 